\title{
Online Representation of Azerbaijani Online Community
}

\author{
Lala Hajibayova \\ Indiana University, Bloomington,USA
}

\section{Introduction}

Three important historical events during the Soviet regime affected emigration of Azerbaijanis: the invasion of the Bolsheviks and the establishment of the Soviet regime, the Second World War (captured Soviet soldiers were not allowed to return) and the collapse of the regime itself. As a consequence of these political changes, there have been three waves of diasporic flow in the $20^{\text {th }}$ century forcing many Azerbaijanis to Western European and North American countries. Later on these displaced citizens become a "core" of the Azerbaijani Diaspora abroad.

Another notorious historical event is reflected in the labeling of the Azerbaijani Diaspora as Northern and Southern Azerbaijanis, the Treaty of Turkmanchai signed between Russia and Iran in 1828. Today, this settlement, which divided the Azerbaijani-speaking population into two parts, is considered a symbol of "historical injustice" (Swietochowski, 1995, p. 7) concluded without hearing the voice of Azerbaijanis. Severe implications of the treaty echoed in the lives of thousands of people during the Soviet period while borders to the "noncommunist" world were literally shut down.

\section{Diaspora Studies}

The notion of diaspora originally referred to the Jewish population residing outside of Palestine (Oxford English Dictionary). Today's definition represents a status of ethnic minority that not only symbolizes the culture, traditions and heritage of homeland but also its strong ties with it (Androutsopoulos, 2006; Sinclair \& Cunningham, 2000; Kaldor-Robinson, 2002). Cohen (2008), based on Wittgenstein's meaning of fibres, identifies the following nine main features of diaspora: "traumatic dispersal" from country of origin, "expansion from a homeland", "collective memory and myth about the homeland" , "idealization of the supposed ancestral home", "return movement", "strong ethic group consciousness", "troubled 
relationship with host societies", "sense of co-responsibility" with other ethic members, "possibility of a distinctive creative, and enriching life in tolerant host countries" (p. 162).

Media and communication technologies have been unarguably considered as a key tool in diaspora formation and development (Whitaker, 2004; Dahan \& Sheffer, 2001; Graham and Khosravi, 2002; Thompson, 2002). Hiller and Franz (2004) study of Internet use among Canadian internal migrants demonstrates that computer mediated communication is an important tool to connect "people in place with those who are out of place" (p. 747) or, in other words, with homeland. Kaldor- Robinson's (2002) study of Croatian and Kosovar Albanian diaspora use of video and satellite technology displays that "conflicts in the homeland help to radicalize the diaspora and tend to lead individuals either to form stronger identifiers as members of a nation, or, more rarely, to assimilate to a greater extent to their adopted land" (p. 184). Androutsopolous' (2006) research on linguistic diversity of German-based diaspora websites illustrates that the language codeswitching "tailored to the requirements of different modes within a website" ( $p$. 520) helps to "negotiate identities that are related to the diaspora and its virtual discursive spaces" (p. 520). Ong's (2003) argues that the Internet facilitates formation of "new kinds of disembedded diaspora" and cyber diaspora politics that "intervene on behalf of co-ethnics in distant lands" might be a "danger" (p. 82). Graham and Khosravi (2002) argue that multifaceted and diverse online representation of Iranian diaspora questions an existence of a "single" Iranian diaspora. Thomson (2002) also argues that the "idea of a single, nation-state based identity is giving way to a more fragmented and hybridized spectrum of cultural identities" (p. 417). Fung (2007) finds cyber life-real life connection "discouraging" (p. 138) aruguing that "pervasiveness of capitalist and competitive life and its ability to penetrate into the new promised land- the Internet" (p. 138). Ignacio (2007) emphasizes importance of analyzing "utterances and responses" ( $p$. 188) to understand "culture in practice and to learn about their reciprocal systematic relationship, not just effects of structure and practices" (pp. 188-189).

Overall, reviewed literature along with the impact of "new media" on diaspora development, suggest the centrality of the notion of "homeland" to address "issues of identity and belonging in migrant contexts" (Mallapragada, 2006, p. 194).

\section{Sampling and Research Questions}

This paper aims to explore online representation of the Azerbaijani Diaspora through ethnographic research of the most popular listserves, forums and websites. 
In order to allow the unique characteristics of the diaspora online communication to emerge, Glaser and Strauss's (1967) grounded theory approach was employed.

Based on Huseynov's (2008) research and Yahoo! and Google searches (using such keyword searches as Azerbaijan, USA, diaspora, migration), following listserves, forums and websites of Azerbaijani Diaspora were identified:

Listserves/Discussion groups: YDNet, Azerbaijan Studies Forum (Interactive portal): Baku Pages (www.bakupages.com)

Websites: Azerbaijan Society of America (www.usa.azeris.org), US Azeris Network (http://www.usazeris.org), Azerbaijani American Council (http://www.azeris. org), American Cultural Society of Northern California (www.acsnc.org), HoustonBaku Sister Cities Association (http://www.houstonbaku.com)

Social Network Site: Facebook Azerbaycan Diasporasi, Yeni Dostlar (YDnet), Azerbaijani Youth Network of America (AYNA), Alumni Network Azerbaijan groups.

Textual messages posted on the above-mentioned listserves, forums, social network sites and websites were analyzed for the period of two years (from January 2006 up to January 2010).

The following research questions guided this research:

What are the main themes of Azerbaijan Diaspora online discussions?

Does Azerbaijani Diaspora represent/manifest itself as a community (a sense of communion)?

How do diaspora relations with homeland represented online?

\section{Discussions}

\section{Azerbaijani Diaspora in the United States}

The first wave of Azerbaijani immigrants to the United States was mainly comprised of German prisoners of the World War II who arrived to the United States in the early 1950s. It also included refugees who fled from the country after the demise of the Azerbaijan independent government and managed to make their way to the States in the 1950s and 1960s. By the late 1970s there were 
approximately 200 Azerbaijani immigrant families residing in the United States (Thernstrom et al., 1980).

According to the Azerbaijan State Statistical Committee, since the collapse of the Soviet Union (particularly for the period of 1990-2006), approximately half a million of the population migrated from the country (see Table 1):

Table 1. Azerbaijan Population Migration, 1990-2006

\begin{tabular}{|l|l|}
\hline Year & $\begin{array}{l}\text { Number of Migrated } \\
\text { Population }\end{array}$ \\
\hline 1990 & 137.900 \\
\hline 1991 & 106.400 \\
\hline 1992 & 49.900 \\
\hline 1993 & 28.500 \\
\hline 1994 & 19.600 \\
\hline 1995 & 16.000 \\
\hline 1996 & 13.200 \\
\hline 1997 & 15.700 \\
\hline 1998 & 10.500 \\
\hline 1999 & 9.100 \\
\hline 2000 & 9.900 \\
\hline 2001 & 7.300 \\
\hline 2002 & 4.300 \\
\hline 2003 & 3.800 \\
\hline 2004 & 2.800 \\
\hline 2005 & 2.900 \\
\hline 2006 & 2.600 \\
\hline Total & 440.400 \\
\hline
\end{tabular}

Based on the U.S. Census data on the foreign-born population for the period of 1990-2000 4,105 of people born in Azerbaijan entered the United States as naturalized US citizens and 8,395 as non- US citizens, respectively (see Table 2). Comparison of both statistical data for the period of 1990-2000 (see Table 1) shows that Azerbaijani immigrants to the US represent about $0.99 \%$ and $2.01 \%$ of the total migrated population. According to the Azerbaijan Statistical Committee demographic data on migration, the majority of the population migrates to the Russia, Commonwealth of Independent States (CIS) and other Central and Western European countries. Having a comparatively small number of population migrated 
to the United States, one can assume strong representation of Azerbaijani diaspora in the countries of major migration flow (i.e., Russia and other CIS countries).

Table 2. U.S. Census data on United States Azerbaijan-born population, 2000

\begin{tabular}{|l|l|}
\hline United States Azerbaijan-born population & Number \\
\hline U.S. Citizenship and period of U.S. entry & \\
\hline Naturalized U.S. citizen & 5530 \\
\hline Entered 1990 to 2000 & 4105 \\
\hline Entered 1980 to 1989 & 945 \\
\hline Entered before 1980 & 475 \\
\hline Not a U.S. citizen & 8675 \\
\hline Entered 1990 to 2000 & 8395 \\
\hline Entered 1980 to 1989 & 180 \\
\hline Entered before 1980 & 105 \\
\hline Total population & 14205 \\
\hline
\end{tabular}

\section{Online Representation of Azerbaijani Diaspora}

Restoration of independence of Azerbaijan in 1991 opened new perspectives of democratic development for the country. It also created more opportunities for a new generation of Azerbaijanis, mainly the opportunity to study and work abroad. According to Huseynov (2008) the first-ever Azerbaijani listserv - E- Majlis - was launched in 1995 by students studying in the United States. In fact it attracted not only students having access to the Internet but also representatives of the Azerbaijani Diaspora as students usually strive to meet their compatriots residing in/close to their location and engage into Diaspora activities. Later, it was transformed to the YDnet list, which became one of the largest forums of discussion of issues related to Azerbaijan and Azerbaijanis (Huseynov, 2008). As Internet technologies developed, it encouraged new online discussion groups and resources, but YDnet list remains the most active. Moreover, YDnet in comparison to other lists, has always been at the forefront in promoting Azerbaijan, by raising its profile and debating issues challenging the newly independent country. YDnet listserv subscribers are mainly concerned with current social, political and economic issues related to Azerbaijan. By the middle 1990s, when newly independent Azerbaijan lacked an information infrastructure, YDNet moderators pioneered the distribution of English- language news (thru Habarlar-L (News) list) covering Azerbaijan and its surrounding region to break through the information vacuum that surrounded the newly independent state. In fact, it was the first Azerbaijani online group that employed media monitoring and grassroots 
campaigning (Huseynov, 2008). YDnet subscribers react to every manifestation of misinformation and/or misinterpretation of Azerbaijan related issues, such as lack of recognition of Azerbaijan's territorial integrity or the misinformation on the Nagorno- Karabakh war. Accordingly, for over ten years, this group serves as a productive force of the processes affecting Azerbaijanis both in and outside of the country.

Azerbaijan Studies is a forum of scholars dedicated to issues related to Azerbaijan. One of the distinctive features of the group is a number of members who are scholars from all around the world interested in Azerbaijan Studies.

Baku Pages, created in 1998 by a group of Bakuvians residing in the United States (Bakupages.com, 2009), is one of the distinctive interactive web portals bringing together former residents of the capital of Azerbaijan, Baku (i.e. Bakuvians) and Azerbaijanis from all around the world. Bakuvians, regardless of their national identity - Azerbaijanis, Russians, Jews, Armenians and many more - share a common origin and culture of the cosmopolitan capital of Azerbaijan.

In addition to online discussion groups and listserves, there are a number of websites representing the variety of institutions operating in different parts of the United States to coordinate and promote activities of the Azerbaijani Diaspora, such as US Azeris Network (http://www.usazeris.org/), and Azerbaijan Cultural Society of Northern California (http://www.acsnc.org/index2.html ), and HoustonBaku Sister Cities Association (http://houstonbaku.org/). These localized communities guide grassroots activities to set up a framework for community advocacy as well as to reassert Azerbaijani identity through cultural, educational and civic programs.

However, emergence of social network sites, such as Facebook and Twitter, has been shifting representation of Azerbaijani community from the listserv and websites to social network sites. For example, Facebook page of Azerbaijan Society of America (ASA), first Azerbaijani diaspora organization in the United States established in 1957, one of the popular pages of Azerbaijani community .

\section{Azerbaijani online community}

Community is a diffuse concept: what is meant by community varies not only from one discipline to another but also from culture to culture. According to the Oxford English Dictionary, the word community derives from the Latin word comm ${ }^{\bar{u}}$ nis, meaning "fellowship, community of relations or feelings." However, in Medieval 
Latin it was similar to universitas, used in the sense of "a body of fellows or fellow-townsmen". In Medieval Latin and Romanic it was extended to encompass the notion of "common citizenship" and a "community" or "body of fellowcitizens". How can we define today's multifaceted meaning of community? It seems that anything can be a community, from a small group of people with a shared locale to a multitude of people using the same online application. According to the Encyclopedia of Community (2003), the earliest communities served to defend and coordinate actions against predators, made accessible the intensive care required by human infants, and afforded information exchange. This notion of community still holds true today. However, new technologies and emergence of the Internet have drastically changed the sense of community, catalyzing the development of a new type and form of community - community without traditional physical boundaries, place, and language of communication. In this regard, Anderson's (1991) concept of nationality as an "imagined community" (p. 6) is applicable to the notion of online communities since it can be imagined as a nation "because the member of even the smallest nation will never know most of their fellow-members, meet them, or even hear of them, yet in the minds of each lives the image of their communion" (p. 6). The idea of online community is also similar to the idea of the nation as an analogue of the "sociological organism moving calendrically through homogeneous, empty time" (p. 26). Hence, thousands of Azerbaijanis who are members and participants of various online discussion groups, listserves and networking sites hardly know those who they share "online space", however, they do share common beliefs, values, traditions and culture at large of the Azerbaijani nation. As stated by Anderson (1991), each of them has confidence in each other's "steady, anonymous, simultaneous activity" (p. 26) and the sense of "communion" (p. 6) is unconsciously embedded into the minds of every Azerbaijani.

At the same time, some of the users are, in a way, alienated from today's Baku and Azerbaijan. For instance, users of Baku Pages portal seemed to be connected to an Azerbaijani community only through connection to their "old friends" and nostalgia for "old days." In this regard the Baku Pages list of Communities \& Clubs is quite exemplary. The top three most represented groups are Schools (150), Baku- present and past (34) and Cities of Bakuvians (28). All these groups aim to bring together classmates, people who lived or/and currently reside in the same neighborhood of Baku and people who currently reside in different parts of the world. Even though the Internet is featured by its "placeness" (Harrison \& Dourish, 1996, p. 72) "emerg[ing] without an underlying notion of space" (p.72), the observed manifestation of "belonging" demonstrates a users' strong attachment to physical place. As a result, they could not "escape into a self-enclosed cyberian apartness" (Miller \& Slater, 2001, p.5). Each of these popular groups contain 
subgroups, such as listing of high schools (Schools), Baku districts (Baku -present and past) and listing of cities in different part of the world (wherein 10 out of 28 cities are cities of the United States). These groups serve as a meeting point for classmates, by posting old and current images of themselves and the area of the city they lived, and discussing their past and present experiences. Along these lines, for instance, one of the most popular discussions on New York subgroup of the Cities of Bakuvians group was discussion whether immigrants dislike working for their counterparts (246 posting). The user, who initiated the discussion, was arguing that a Russian-speaker's salary in a Russian New York based company is very low.

“Когда русскоязычный человек устраивается работать в ньюйоркскую русскоязычную компанию, он может быть почти уверен, что заработная плата у него будет дерьмовая." (Translation from Russian: "once Russian-speaker employed by a New York based Russian company he should be almost sure that his salary will be crappy”) (Baku Pages, April 24, 2009)

Moreover, names of the subgroups themselves represent a particular generation of Bakuvians users. For instance, one of the districts of Baku is listed with its Soviet period and current name- Kirov (Rasulzade), another one with its pre-Soviet name - Telefonno-Torgovoe.

Although the Azerbaijani community is a community of one nation, it is distinguished by a "genuine polyphony of fully valid voices" (Bakhtin, 1984 p. 6) of Southern and Northern Azerbaijan. While the Southern Azerbaijani community voices violations of human and civil rights of millions of Azerbaijanis, the Northern Azerbaijani community voices violations of its territorial integrity, along with political, economic and cultural challenges faced by a newly independent country. Moreover, they differentiate by culture and language. Southern Azerbaijanis are affected by a strong influence of Iranian culture, while Northern Azerbaijanis are influenced by Russian and Western European cultures. Difference in written language is present since Southern Azerbaijanis do not have an opportunity to get a formal education in Azerbaijani language. As cited in Shaffer (2002), mainstream Iranian contemporary studies justify the lack of formal education in Azerbaijani with the fact that Azerbaijanis are a "well-integrated minority" and "have assimilated into Iranian identity" (p. 5). Additionally, there is a difference in alphabets as well - Arabic script in Southern Azerbaijan and Latin in Northern Azerbaijan - makes written communication even more complicated. It is worth noting that the issue of the alphabet was very politicized or as noted by Anderson (1991), "conscious[ly] manipulate[ed]" (p. 45) in Northern Azerbaijan. 
The base of the written language has been changed four times throughout history: Arabic, Latin, Cyrillic and back to Latin. These changes resulted in a painful disconnect between Southern and Northern Azerbaijan, and, more importantly the lack of a common print-language of communication and education between generations.

\section{Language code-switching}

Azerbaijanis preferable language of communication reflects not only their cultural and educational background but also the generation of Azerbaijanis they belong to. People who lived in Soviet Azerbaijan are very comfortable speaking in Russian and writing in Cyrillic script Azerbaijani. Today's young generation of Azerbaijanis speaks and writes in Latin script Azerbaijani, because after the collapse of the Soviet regime, language was switched back to Latin Script. In this sense Baku Pages is especially exemplary, attracting mainly Russian-speaking Azerbaijani Bakuvians, who currently reside outside of the country. Obviously, the discourse analysis exemplifies "code-switching" (Auer, 1999, p.17), and the pattern of switching languages from Azerbaijani to English, Russian to English, or all three languages at a time appeared to be a common characteristic of the analyzed discourse. An excerpt from YDNet listserv discussion on a protest meeting against the recognition of Armenian genocide in Washington, DC exemplifies a codeswitching from Azerbaijani to English:

"Sagolun, Bedir gardas. Cox buyuk ve etkili bir eylem etmissiniz. (Translation from Azerbaijani: Thanks, Bedir brother. You did a great job)

A great cooperation and effective counter-demonstration indeed."(YDnet listserv, April 25, 2009)

\section{Diaspora and homeland}

In-line with reviewed diaspora studies, Internet technologies play a critical role for Azerbaijani Diaspora not only to connect but also actively to participate in everyday life of the home country. Territorial integrity of Azerbaijan, NagornoKarabakh war, human and civil rights of Azerbaijanis in Iran, history... basically, every other issue related to Azerbaijan and Azerbaijanis is a subject of discussion. For instance, change in presidential term limit and gun attack at Baku Oil Academy exemplify strong diaspora links to the homeland. When the majority of Parliament members voted to call a nationwide referendum to remove the presidential term limit, only oppositional political parties voiced their concern and summoned to boycott the referendum. Diaspora reaction to the possible major political structural change was diverse. One group of people, including students currently studying in 
the United States, called for a protest meeting and actions to protect the country's democratic values, while another group mainly those representing diaspora, hardly expressed any concern. It appeared that the diaspora itself reflects the major political flows of the country - pro-governmental and opposition. The posting addressed to Facebook Azerbaijani Youth Network of America calls for action against removal of presidential limit referring to the country's historical democratic values:

"Dear Azerbaijani-Americans and everyone else who cares about the future of DEMOCRACY in our part of the world,The Azerbaijani-Americans for Democracy (AZAD) group invites all of you to join us for a rally in front of UN Headquarters in New York City. If you treasure the survival of Azerbaijan's national statehood, the freedom and prosperity of its people, if you object to the country turning into a de-facto monarchy - please make your voices heard loudly and clearly. Let us RESPECT and REGARD our REPUBLIC. Let us demonstrate to the world that Azerbaijanis value the ideals of liberty and democracy. We believe in our FUTURE deeply rooted in our ADR heritage and its spirit. The fathers of ADR, the leaders of the first recognized democratic REPUBLIC in the Muslim world, started our long way to freedom in 1918 from the belief that democratic REPUBLIC is possible also in Muslim society...." (Facebook Azerbaijani Youth Network of America Group, January 9, 2009)

For the last couple years, Azerbaijan Government has been proactive in engaging with diasporic organizations all around the world. For instance, the government has organized the Forum of World Azerbaijanis since 2001. It also, in cooperation with diaspora organizations, organizes conferences, protest meetings and public talks. The relationship of diaspora with government institutions may also affect its position with regard to political changes in the country.

One of the illustrations of the critical role of the Internet technologies in diaspora life is tragic event at Azerbaijan Oil Academy. The posting and link to a local news agency report about a gunman who shot dead 13 and wounded a dozen of students and faculty at a top academic institution in Baku appeared on YDNet listserv within less than two hours after the tragic event. Later on discussions, links to news reports, videos, pictures and witnesses' messages appeared all across the listserves, portals and Facebook social network groups. Listserv subscribers complained that local TV stations aired news about the tragic event long after it was reported on online news agencies. Apparently, diaspora listserv members reacted to the tragic event faster than local TV stations in spite of being thousands of miles away from the homeland. Facebook Alumni Network Azerbaijan group and listserves called upon those currently residing in Baku to pay tribute victims of 
the tragedy and lay down flowers and candles at the university building. On the day of the tragic event, two major diasporic organizations - Azerbaijani- American Council and Azerbaijan Society of America - distributed their joint statement mourning victims of the tragedy:

"Remembering similar massacres at Columbine and VirginiaTech in the United States, Azerbaijani-Americans express their outrage over this senseless act of violence which took place in an academic institution. At this tragic moment, members of Azerbaijani-American Council and Azerbaijan Society of America join Azerbaijani nation in mourning for the victims, offering our deepest condolences to their families and friends. We call for expedient measures to ensure safety and security at academic institutions across Azerbaijan.

We call for a Moment of Silence in memory of the victims to be held by Azerbaijani-Americans on the 3rd day after the tragedy - May 2nd @ 6:00PM Eastern Standard Time." (YDNet listserv, April 30, 2009)

Again, this tragic event exemplifies a critical role of Internet communication for the diaspora and its close relation to the homeland.

Another major activity of the diaspora organizations is lobbying interests of the country. Diaspora constantly engages letter-writing campaigns, protest meetings and rallies to voice Azerbaijani community needs and concerns, and to promote culture and traditions of Azerbaijan. Diaspora organizations are also involved with watchdog and advocacy activities to ensure that national interests and justice are respected. For instance, one of the YDNet users questioned why the UN resolution on Nagorno Karabakh which called for the immediate, complete and unconditional withdrawal of Armenian forces from all the occupied territories of the Republic of Azerbaijan was taken down from the US State Department website:

"Did you folks notice that the U.S. State Department silently removed its page on the 1993 UN Security Council resolutions regarding Karabakh? http://www.state. gov/p/eur/rls/or/13508. htm" (YDNet Listserv, April 7, 2009)

Online discussion groups are also playgrounds for the scholarly battle of ideas, valuable for its diversity of opinion and thought. Thus, a posting on Azerbaijan Studies inviting one to join a Facebook group dedicated to Mammademin Rasulzadeh, the first President of Azerbaijan Democratic Republic, turned into a debate over its controversial cooperation with the Nazis government during the World War II: 
"And here is another good reference from Professor Audrey Altstadt: "Azerbaijani Turkish Immigrants living in Berlin before the war, including the former head of the Musavat, Mehmet Emin Rasulzade, were hardly fascist but, like those in Paris and Istanbul, were certainly Anti-Soviet." (Audrey L. Altstadt. "The Azerbaijani Turks: Power and Identity under Russian Rule", Hoover Press, 1992, p. 157)

So, you can't really blame people like Rasulzadeh holding the worst view of Bolsheviks than that of Nazis. Just before the war, in 1937, hundreds of thousands of Azerbaijanis, including most of the intellectual elite were purged, killed, or deported by Bolsheviks. So I would say Rasulzadeh's view then was pretty much similar to how modern Estonians, Latvians and Lithuanians treat Nazis vs. Soviets in their perceptions of history and present"(Azerbaijan Studies listserv, October 29, 2008)

Patterns observed on groups of social networking sites, such as Facebook's Azerbaycan Diasporasi, Yeni Dostlar (YDnet), Azerbaijani Youth Network of America (AYNA), Alumni Network Azerbaijan groups are consonant with concerns voiced in the analyzed listserves. Surprisingly, the dynamics of these discussions do not correlate with ones observed on "traditional" listserves, which might be explained by the relatively low popularity of the social networking sites among middle-age users (InsideFacebook.com 2010). Interestingly, these groups are used mainly to call for action and participation on certain event rather than discussions.

"COMMUNITY DEMONSTRATION To Commemorate the Anniversary of Khojali Massacre And Protest Armenia's Occupation of Western Azerbaijan

This event, organized by local community members, has been coordinated with Washington DC Metropolitan Police and Secret Service. Sound equipment and signs will be provided, but participants are free to bring their own signs, posters, and flags. DEMAND JUSITCE FOR KHOJALI VICTIMS! SAY NO TO ARMENIAN MILITARY PRESENCE IN WESTERNAZERBAIJAN! SHOW YOUR SUPPORT FOR AZERBAIJAN'S TERRITORIALINTEGRITY!' (Facebook AYNA Group message to group members, January 28, 2009)

Hall's (1994) definition of "identity as a 'production', which is never complete, always in process, and always constituted within, not outside, representation" (p. 222) can be applied to Azerbaijan online diaspora identity. Being thousands of miles away from the country of its origin, the diaspora engaged an ongoing process of representing itself as a nation with its unique traditions and historical heritage. It is a little wonder that this distinguishing feature is manifested in its online 
representation as well. Moreover, images posted from Diaspora events and the design of Diaspora websites represent cultural heritage and national symbols, such as Azerbaijani flag, colors of the flag, and national ornament.

\section{Conclusions}

Azerbaijan is a borderland at a crossroads of history, cultures, beliefs, traditions and values, which manifest in its online representation. It also comprises unique and distinctive features of its multifaceted identity - identity which is profoundly influenced by Russian culture, Muslim beliefs and European values. It represents, in Bakhtin's (1984) term, a polyphony of nation's voices - Northern and Southern Azerbaijan. Although as a community it is imagined (Anderson, 1991), it is a vital part of Azerbaijani "metaculture of traditions" (Urban and Lee, 2001, p.5), which is manifested through mediated computer communication and online visual representation. Azerbaijani diaspora also exemplifies Cohen's (2008) features of the diaspora, such as "expansion from homeland", "collective memory and myth about the homeland" and "strong ethic group consciousness" (p. 162).

This study demonstrates a critical role of Internet technologies that connect, mobilize and represent Azerbaijani online community. It provides the "dominant means of exchange of information within translocal community" (Mader, 2007, p. 232). In a way, the analyzed online communication resembles Bauman's defined notion of performance wherein postings are acts of "situated behavior, situated within and rendered meaningful with reference to relevant contexts" (p. 298). It illustrates a strong relation to its context as a nation at large.

Obviously, the development of Internet technologies catalyzed the formation of an Azerbaijani Diaspora as a distinctive online community. In spite of being virtual, it is realized as an authentic representation of the Azerbaijani nation with a promising future. As argued by Boellstorff (2008), "through culture, humans are always already virtual; ethnography has always been a kind of virtual investigation of the human, and can therefore play an important role in understanding cybersociality" (p. 249).

\section{References and Notes}

Anderson, B. (1991). Imagined communities: Reflections on the origin and spread of nationalism. London: Verso. 
Androutsopoulos, J. ( 2007). Multilingualism, diaspora, and the Internet: Codes and identities on German-based diaspora websites, Journal of Sociolinguistics, 10( 2), 520-547.

Azerbaijan State Statistical Committee. International migration of the population. Retrieved from http://www.azstat.org/statinfo/demoqraphic/az/AP_/AZ_1.shtml

Azerbaijani_Studies Yahoo Group. Retrieved from http://groups.yahoo.com/group/ Azerbaijani_Studies/.

Auer, P.(1999). Code-switching in conversation: Language, interaction and identity. New York: Routledge.

Bakhtin, M. (1984). Problems in Dostoevsky's Poetics. Minnesota: University of Minnesota Press.

Bakupages.com. Retrieved from http://bakupages.com

Boellstorff, T. (2008). Coming of age in second life: An anthropologist explores the virtually human. Princeton: Princeton University Press.

Bauman, R. (1975). Verbal art as performance, American Anthropologist, 77(2), 290-331.

Christensen, K. \& Levinson, D. (2003). Encyclopedia of community: From the village to the virtual world. Thousand Oaks: Sage.

Cohen, R. (2008). Global diasporas: An introduction. New York: Routledge.

Dahan, M. \& Sheffer, G. (2001). Ethnic groups and distance shrinking communication technologies, Nationalism \& Ethic Politics, 7(2), 85-107.

Glaser, B. \& Strauss, A. (1967). The discovery of grounded theory: strategies for qualitative research. New Jersey: Aldine Transaction.

Ignacio, E. (2006). E-scaping boundaries: Bridging cyberspace and diaspora studies through nethnography," In: D. Silver \& A. Massanari (Eds.), Critical cyberculture studies (pp. 181-193). New York: University Press.

Inside Facebook. December data on Facebook's US growth by age and gender: Beyond 100 million. Retrieved from http://www.insidefacebook.com/2010/01/04/december-dataon-facebook\%E2\%80\%99s-us-growth-by-age-and-gender-beyond-100-million/

Graham, M. \& Khosravi, S. (2002). Reordering public and private in Iranian cyberspace: Identity, politics, and mobilization, Identities: Global studies in culture and power, 9(2), 219-246.

Fung, A. (2006). Bringing cyberlife and real life: A study of online communities in Hong Kong. In: D. Silver \& A. Massanari (Eds.), Critical cyberculture studies (pp.129-139). New York: University Press.

Hall, S. (1994). Cultural Identity and Diaspora. In: J. Braziel \& A. Mannur (Eds.), Theorizing diaspora: A reader (pp. 233-243). Oxford, UK: Blackwell Publishing.

Harrison, S. \& Dourish, P. (1996). Re-place-ing space: the roles of place and space in collaborative systems. Proceedings of the 1996 ACM Conference on Computer supported cooperative work, Boston, USA, pp. 67-76.

Hill, H. \& Franz, T. (2004). New ties, old ties and lost ties: The use of the Internet in diaspora, New Media \& Societ, y 6(6), 731-751.

Huseynov, J. (2008). The role of online communities in the development and formulation of Azerbaijani national identity. Paper presented at the meeting of the Association for 
the Study of Nationalities 2008 World Convention, Columbia University, New York, NY.

Kaldor-Robinson, J. (2002). The virtual and the imaginary: the role of diasphoric new media in the construction of a national identity during the break-up of Yugoslavia, Oxford Development Studies, 30 (2), 177-186.

Mallapragada, M. (2006). An interdisciplinary approach to the study of cybercultures In: D. Silver \& A. Massanari (Eds.), Critical cyberculture studies (pp. 129-139). New York: University Press.

Miller, D. \& Slater, D. (2001). The Internet: An ethnographical approach. New York: Berg.

Mader, E. (2007). Encounters with Otavalo. Ritual, Identities, and the Internet. In R. Mursic \& J. Repic (Eds.), Places of encounter: In memoriam Borut Brumen (pp. 221238). Ljubljana, Slovenija: Zupanjceva knjiznica.

Ong, A. (2003). Cyberspace and diaspora politics among transnational Chinese. Interventions, International Journal of Postcolonial Studies, 5(1), 82-100.

Oxford English Dictionary. (n.d.). Online Retrieved from http://bert.lib.indiana.edu:2055/entrance.dtl.

Shaffer, B. (2002). Borders and brethren: Iran and the challenge of Azerbaijani Identity. Cambridge, Mass.: MIT Press.

Sinclair, J. \& Cunningham, S. (2000). Go with flow: Diasporas and the media, Television \& Media 1, 11-31.

Swietochowski, T. (1995). Russia and Azerbaijan: A Borderland in Transition. New York: Columbia University Press.

Thernstrom, S., Orlov, A. \& Handlin, O. (Eds.).(1980). Harvard encyclopedia of American Ethnic groups. Cambridge: Harvard University Press.

Thomson, K. (2002).Borders crossings and diasporic identities: Media use and leisure practices of an ethnic minority. Qualitative Sociology 25 (3), 409-418.

United Nations. (n.d.). Azerbaijan 1998 Annual Report. Retrieved from http://www.unaz.org/r1.htm.

Urban, G. \& Lee, B. (2001). Metaculture: How culture moves through the world. Minnesota: University of Minnesota Press.

U.S. Census Bureau. 2000 United States foreign-born population [Data file]. Retrieved from http://www.census.gov/population/cen2000/stp-159/STP-159-Azerbaijan.pdf

Whitaker, M. (2004). Talminet.com: Some reflections on popular anthropology, nationnalism, and the Internet. Anthropological Quarterly 77(3), 469-498. YDnet Yahoo Group. Retrieved from http://groups.yahoo.com/group/YDnet. 


\section{Summary}

\section{Online Representation of Azerbaijani Online Community \\ Lala Hajibayova \\ Indiana University, Bloomington, USA}

This paper discusses online representation of Azerbaijani Diaspora of post Soviet era. Diaspora websites, discussion groups and forums are analyzed to explore how critical historical moments of newly independent country manifested in its online representation. Analysis of online representation of Azerbaijani diaspora in the United States reveals diaspora's strong connection with homeland that expressed through lobbying of its interests, immediate and constant reaction to the on-going processes in the home country. Study displays a critical role of Internet technologies in representation and formation of Azerbaijani Diaspora as a community.

Keywords: Azebaijani Diaspora, Azerbaijan online representation, Azerbaijani community in the United States 